\title{
A Research on Learning Approaches and Achievement Focused Motivations of Prospective Visual Arts Teachers
}

\author{
Selma Taşkesen ${ }^{1}$ \\ ${ }^{1}$ Education Faculty, Erzincan Binali Yıldırım University, Erzincan, Turkey \\ Correspondence: Selma Taşkesen, Education Faculty, Erzincan Binali Yıldırım University, Erzincan, Turkey.
}

Received: June 5, 2019

Accepted: July 21, $2019 \quad$ Online Published: December 30, 2019

doi:10.5539/ies.v13n1p123

URL: https://doi.org/10.5539/ies.v13n1p123

\begin{abstract}
Investigating the relationship between the learning approaches and achievement-focused motivations of the prospective visual arts teachers is the purpose of this study. The data of the research, in which the survey model was employed, were collected from 115 prospective visual arts teachers. As the data collection tool, the Achievement Focused Motivation Scale (AFMS), and the Learning Strategies Scale (LSS) were applied. The descriptive analysis was used to test the learning approaches and achievement-focused motivation levels of the prospective visual arts teachers, the independent samplings t-test to test the achievement focused motivation difference according to the gender, the One-way Variance Analysis to investigate the difference according to the class level. According to the research, it was found that the achievement focused motivation levels of the prospective visual arts teachers was pretty high; nevertheless, no significant difference was found in the achievement focused motivation levels according to the gender and class level. However, a significant difference was encountered in the Learning Approach dimension according to the class level. In addition, it was found in the study that a positive, high level of relationship was observed between the Achievement Focused Motivation and the Learning Approaches, In-depth Teaching Approach and Strategic Approach.
\end{abstract}

Keywords: visual arts teaching, achievement focused motivation, learning approaches

\section{Introduction}

\subsection{Introduce the Problem}

Students with different characteristics are educated together in education and training environments. Each student has different characteristic features, different abilities, different learning habits and changing motivation levels depending on these features. For this reason, learning approaches are considered as a variable that reveals personal differences among students. How students handle the learning task and how they are influenced by the environment has a decisive impact on learning products (Ekinci, 2009). As it is evaluated in general, "learning is doing, not forgetting what is learned, gaining habits and understanding" (Kayar, 2004). Several kinds of research were conducted on learning. "How soon, with what methods, in what sense organs and how it occurred, have been the focus of studies on learning. In recent years, the answer to the question 'How is learning permanent?' has been on the agenda" (Ozgur \& Tosun, 2013). And this case brings along the concept of learning approaches. The learning approach refers to the direction of the student (meaning search, memorization, success, etc.) that arises depending on the intention of the student in addressing the subject of learning. The first pioneering studies in higher education on students' learning approaches began in the mid-1970s (Ekinci, 2009). Marton and Saljo (1976) who had conducted studies on these years, a group of university students were asked to read a scientific survey and answer some questions related to the subject they had read. Some of the students had preferred to memorise the text only to answer the questions in the research. Marton and Saljo (1976) explained this case as "superficial learning". The other students, on the other hand, took the subject as a whole and tried to understand the meaning by associating them with pre-learning, new ideas and experiences. This second situation is defined as "deep learning". In the research, it was also found that there is a relationship between learning approaches and understanding levels. As a result, it was seen that even after a long time, deep learners could remember more information and details (Marton \& Saljo, 1976a, pp. 4-11; 1976b, pp. 115-127). Ramsden (1979), after the studies on both deep and superficial learning, identified a third learning approach which he called "strategic approach" in another study. Then, Biggs (1987), who had conducted studies on the same field, named the strategic approach as the achievement approach. As it is mentioned above, in fact, it is seen that the learning approaches are determined by 
the intention of the student in teaching.

As the content qualifications of the Superficial, In-depth and Strategic Learning Approaches are taken into consideration, the superficial learning approach is a learning approach that meets the requirements of the task.

"Memorizing without the understanding of the content is s one of the most commonly used strategies in the superficial learning approach" (Biggs, 1991). The student, acting with a superficial learning approach, tries to keep everything related to his/her work in mind in the process of the study. According to Chan (2003), the superficial learning approach reflects the belief that learning ability is fixed, that information is presented by authority, and that information is precise and unchangeable. Ramsden (2003) states that students, who prefer this approach aim to fulfill their duties only, memorize information for evaluation, failing to distinguish between principles and examples, and evaluate learning as an external challenge. On the other hand, the deep learning approach aims to improve the academic subjects. This learning approach aims to find meaning by associating reading with old knowledge and new knowledge. "The In-Depth Learning Approach (ILA) is based on the intention of the student to search and create meaning in addressing the learning" (Ramsden, 2003). Students, who follow the deep learning approach, aim to understand and internalize the subject. In this approach, it is not important to remember the details about the subject completely; because what the issue means is more important. İt is known that learning through a deep learning approach spreading over a long period is more permanent than superficial learning. "The strategic approach can be considered as a mixed approach that is composed of the features of In-Depth and superficial learning approaches" (Harlen \& James, 1997). In this approach, the student acts completely according to the conditions of the situation. High marks, competitiveness and success are among the priorities of the students in this group. These students try to secure strategies that will lead them to success. They evaluate many strategies to achieve their desired goals." "High mark, competition and achievement are among the priorities of students in this group. These students are trying to secure strategies that will lead them to success. They seize many strategies to achieve their desired goals.

All three learning approaches are related to student's working potential, personality type and motivation. The person can determine the learning strategy according to the situation $\mathrm{s} / \mathrm{he}$ is in and the current importance level of the subject $\mathrm{s}$ /he wants to learn. The motivation of the person is very vital in this process. For this reason, the necessity of motivation in education processes is an undeniable fact. Motivation can be defined as the force that drives people towards their purpose. Motivation is being motivated, in short. Motivation is a general concept involving human needs. By this means, "The motives stimulate the organism, activate it and direct the behaviour of the organism to a particular purpose. If these features are observed in the organism's behaviour, it is regarded that the organism is motivated (Cuceloglu, 1999). In education, increasing students' motivation is crucial to be successful in their learning processes. Oncu (2000) defined student motivation as the desire of students to be included the learning process. Learning Motivation "Whether it is intrinsically interesting or not, it is that the academic homework is meaningful, valuable and useful in terms of learning" (Ames, 1990). The complementary elements in education and training processes are both student motivation and learning motivation. Deci and Ryan (1985) divided motivation into three main types as intrinsic motivation (IM), extrinsic motivation (EM), and non-motivation to better understand one's psychological state.

Among these, the intrinsic motivation occurs naturally with emotions as interest, curiosity, and need with effect from the inside of the person (Geri, 2013). In the extrinsic motivation which is another dimension of the motivation, the person focuses on the result more. "Instead of enjoying the activity for the individual, the benefits of the activity are seen as the focus" (Ryan \& Deci, 2000). Another dimension of the motivation is the non-motivation. In the manner of non-motivation, "people experience feelings of inability to relate to their actions and consequences, seeing themselves as inadequate and feeling that they cannot control what is happening" (Karaguven, 2012). In this context, it is possible to associate the types of motivation with the learning approaches. The motivation for success is one of the most important concepts in education and training processes. Kaur (2013) defines the motivation for success as "tendency to strive for success or to achieve the desired purpose". Academic achievement is one of the most frequently often targeted dependent variables in the teaching process (Yilmaz, 2014). In academic researches, the relationship between the success variable and many independent variables are investigated. For this reason, the relationship between success and motivation always maintains its importance and timeliness. The motivation for success was classified by McClelland (1961) to meet three different needs: 1) a need for success, 2) a need for membership and 3) a need for power. These needs are learned and shaped according to one's way of life. Liao, Ferdenzi, and Edlin (2012) stated that motivation for success represents a strong predictor of success, perceived success, and academic skill.

As the literature was reviewed, there are studies that are similar to our research on learning approaches (Ekinci, 2008; Ekinci, 2009; Karatas, 2011; Ozan, Kose, \& Gundogdu, 2012; Ozan \& Ciftci, 2013; Ozgur \& Tosun, 2012; 
Olpak \& Korucu, 2014; Ekinci, 2015; Kanadli \& Akbas, 2015). On the other hand, there are similar studies on the achievement focused motivation which is the second dimension of our research (Semerci, 2010; Yilmaz, 2017; Ergin \& Karatas, 2018). It is thought that this study will contribute to the literature with similar studies.

\subsection{Research Objectives}

In this present study, to determine the relationship between the Learning Approaches and the achievement focused motivations of the prospective visual arts teachers who were attending the Department of Art Education, and investigate its effect on their academic achievements.

\subsection{Research Questions}

1) What are the levels of the achievement focused Motivation and Learning Approach (LA) (In-Depth Learning Approach (ILA), Strategic Approach (STRTGCA), Superficial Learning Approach (SLA) scores of the pre-service visual arts teacher?

2) Does a significant difference exist between the mean scores of the prospective visual arts teachers' Achievement Focused Motivation and Learning Approaches according to Gender Variable?

3) Does a significant difference exist between the mean scores of achievement focused Motivation and Learning Approaches according to the Grade Variables?

4) Does a significant relationship between achievement-focused motivation, learning approaches and General Weighted Means Score (GWMS) of prospective visual arts teachers?

5) The general weighted mean score (GWMS) represents the weighted grade average score calculated from all courses taken by the students.

\section{Method}

In this study, it was aimed to investigate the relationship between the learning approaches and achievement-focused motivations of the prospective visual arts teachers. The research was conducted with relational survey model.

\subsection{Study Group}

In this research, from 2018-2019 education year in Art Education Teaching Department, Education Faculty, Erzincan Binali Yildirim University,117 (72 female/40 male/5 unspecified) students from 1st, 2nd, 3rd and 4th grades participated.

To determine the study group, the criterion sampling was applied among the purposive sampling methods. Purposive sampling is a non-probability-based sampling approach that allows in-depth research by selecting information-rich situations depending on the purpose of the research. The researcher tries to understand and explain the nature and society events or phenomena and the relationship between them in the context of selected situations (Buyukozturk, Kilic Cakmak, Akgun, Karadeniz, \& Demirel, 2012).

On the other hand, the criterion sampling is studying and reviewing all situations that meet some predetermined importance criteria (Patton, 2014). These criterion or criteria can be generated by researcher or a list of previously prepared criteria can be followed (Yildirim \& Simsek, 2006).

\subsection{Tools}

Two measurement tools were applied for the collection of necessary data for this research. The Learning Strategies Scale: To determine the learning approaches of the prospective visual arts teachers, the Learning Strategies Scale, developed by Ekinci (2008), was applied. The Learning strategies Scale consists of the dimensions such as (1) In-Depth Learning Approach (ILA), (2) Superficial Learning Approach (SLA) and (3) Strategic Learning Approach (STRTGCA) 54 items are included in the scales which consist of 18 items each. The Cronbach Alpha $(\alpha)$ values calculated for the reliability level of the scale is 89 for the first dimension, 87 for the second and, 85 for the third.

The Cronbach Alpha $(\alpha)$ value calculated for this present study is 92.8 for the first dimension, 92.6 for the second, 90.3 for the third and, 95.1 for the whole.

The Achievement Focused Motivation Scale (AFMS): The Achievement Focused Motivation Scale (AFMS), developed by Semerci (2010), consists of 35 questions. 1 question on the scale is negative, 34 questions are positive. The Cronbach Alpha $(\alpha)$ value calculated for the reliability for the scale was found as 0.80 . Also, the Personal Information Form was applied to get information about the students. 


\subsection{Data Analysis}

The descriptive statistics related to the variables, correlation and variance analyses were tested at the .05 level of significance using the SPSS 22.00 program. Parametric tests were used in the study because of the normal distribution of the data. İndependent samples t-test was used for gender variable and one-way ANOVA test was used for the grade level variable. Besides, the Pearson Correlation Coefficient was used to analyse the correlation between learning approaches and achievement-focused motivation scores.

\section{Results}

3.1 Findings Related to the Mean Scores of the Prospective Visual Arts Teachers in the Achievement Focused Motivations and Learning Approaches Scale (In-Depth Learning Approach, Strategic Approach, Superficial Learning Approach)

Table 1. Descriptive statistics related to finding the levels of the prospective visual arts teachers in the achievement focused motivation and learning approaches scale (in-depth learning approach, strategic approach, superficial learning approach)

\begin{tabular}{lcc}
\hline Variable & $\mathrm{N}$ & $\bar{X}$ \\
\hline AFMS & 117 & 140.44 \\
ILA & 117 & 69.85 \\
STRTGCA & 117 & 68.80 \\
SLA & 117 & 61.74 \\
LA & 117 & 200.38 \\
\hline
\end{tabular}

As Table 1 is analyzed, it is seen that the score means of the prospective visual arts teachers from the AFMS are $=$ 140.44. As it is taken into consideration that is the highest score that can be gotten from the scale is 175 , it can be expressed that the mean scores of the pre-service teachers are pretty high. Besides, as the mean scores of the pre-service teachers related to the Learning Approaches and sub-dimensions are considered, it is noticed that ILA= 69.85, STRTGCA $=68.80$, SLA $=61.74$ and LA $=200.38$. The highest score that can be taken each of the sub-dimensions is 90; the highest score that can be taken from the Learning Approach Scale is 270. Considering this, it can be referred that the Strategic approach and In-Depth Learning Approach mean scores of the prospective visual arts teachers are at a good level; Superficial Learning Approach mean scores are moderate. The in-depth learning approach means increasing the student's mastery of the subject. Therefore, this learning approach is expected to be good and very good. İt can also be claimed that the Learning Approach mean scores are at a good level.

3.2 Findings Related to the Difference Between the Mean Scores of the Prospective Visual Arts Teachers in the Achievement Focused Motivation and Learning Approaches Scale (In-Depth Learning Approach, Strategic Approach, Superficial Learning Approach) According to the Gender Variable

The Independent Sampling T-test results of the prospective visual arts teachers related to the difference in score means in the Achievement Focused Motivation and Learning Approaches Scales (In-Depth Learning Approach, Strategic Approach, Superficial Learning Approach) are presented in Table 2. 
Table 2. The Independent Sampling t-test results of the students related to the achievement focused motivation and learning approaches scale (in-depth learning approach, strategic approach, superficial learning approach) according to the gender variable

\begin{tabular}{lccccccc}
\hline Variable & & $\mathrm{n}$ & $\bar{X}$ & Std. Dev. & $\mathrm{df}$ & $\mathrm{t}$ & $\mathrm{p}$ \\
\hline \multirow{2}{*}{ AFMS } & Female & 72 & 145.90 & 21.07 & 110 & 1.715 & .089 \\
\cline { 2 - 8 } & Male & 40 & 138.80 & 20.87 & & & \\
\hline \multirow{2}{*}{ ILA } & Female & 72 & 71.93 & 11.88 & 110 & .784 & .435 \\
\cline { 2 - 8 } & Male & 40 & 70.18 & 10.32 & & & \\
\hline \multirow{2}{*}{ STRTGCA } & Female & 72 & 70.17 & 11.74 & 110 & -.093 & .926 \\
\cline { 2 - 8 } & Male & 40 & 70.38 & 10.72 & & & \\
\hline \multirow{2}{*}{ SLA } & Female & 72 & 61.79 & 12.98 & 110 & -1.267 & .208 \\
\hline \multirow{2}{*}{ LA } & Male & 40 & 65.00 & 12.57 & & & \\
\hline & Female & 72 & 203.89 & 30.92 & 110 & -.288 & .774 \\
\hline
\end{tabular}

According to Table 2, as the mean scores of the female and male prospective visual arts teachers from the Achievement Focused Motivation Scala (AFMS) are compared, it is seen that the mean scores of the female participants $=145.90$ is higher than the mean scores of male participants $=138.80$. the standard deviation values related to the scale are analysed, the measurements of the male participants $S=20.87$ are more homogenous than the female participants $S=21.07$. According to the independent sample t-test calculated to find out the difference between the scores according to gender $[\mathrm{t}(21)=1.715, \mathrm{p}>.05]$, it is noticed that there is no significant difference. This finding demonstrates that the achievement focused motivations of male and female pre-service teachers are indistinguishable.

According to the Table 2, also as the Learning Approaches (LA) of the female and male prospective visual arts teachers and sub-dimensions: In-Depth Learning Approach (ILA), Strategic Approach (STRTGCA), Superficial Learning Approach (SLA) mean scores are compared, the Learning Approach mean score of the male pre-service teachers $=205.55$, is noticed to be higher than the mean score of the female pre-service teachers $=203.89$, and in the sub-dimensions of the Learning Approach mean scores are in favour of the male pre-service teachers. As the standard deviation values are analysed, it is seen that the measurements of the male participants $\mathrm{S}=25.89$ are more homogenous than female participants $\mathrm{S}=30.92$. According to the independent sampling $\mathrm{t}$-test $[\mathrm{t}(25)=-.288$, $\mathrm{p}>.05$ ]calculated to determine the difference between the scores of female pre-service teachers and male ones, it was found that there was no significant difference. It is understood from Table 2 that, there is no difference between the female and male pre-service teachers' Learning Approaches and In-Depth Learning Approach, Strategic Approach, Superficial Learning Approaches.

3.3 Findings Related to the Difference between the Mean Scores of the Visual Arts Pre-Service Teachers in the Learning Approaches and In-Depth Learning Approach (In-Depth Learning Approach, Strategic Approach, Superficial Learning Approaches) in Terms of the Grade Variable

The results related to the one-way variance analysis (ANOVA) calculated to determine the difference between the scores of the prospective visual arts teachers from the Achievement Focused Motivation and Learning Approaches Scale (In-Depth Learning Approach, Strategic Approach, Superficial Learning Approach) in terms of the grade variable are presented in Table 3. 
Table 3. The results related to the one-way variance analysis (ANOVA) calculated to determine the difference between the scores of the students from the achievement focused motivation and learning approaches scale (in-depth learning approach, strategic approach, superficial learning approach) in terms of the grade variable

\begin{tabular}{|c|c|c|c|c|c|c|c|c|}
\hline Variable & Grade & $\mathrm{n}$ & $\bar{X}$ & Std. Dev. & $\mathrm{df}$ & $\mathrm{F}$ & $\mathrm{p}$ & Df. \\
\hline \multirow{5}{*}{ AFMS } & 1 & 36 & 143.39 & 18.12 & $3-111$ & 1.073 & .364 & \\
\hline & 2 & 37 & 146.78 & 20.39 & & & & \\
\hline & 3 & 20 & 136.30 & 27.06 & & & & \\
\hline & 4 & 22 & 141.45 & 22.67 & & & & \\
\hline & Total & 115 & 142.88 & 21.49 & & & & \\
\hline \multirow{5}{*}{ ILA } & 1 & 36 & 70.89 & 10.54 & $3-111$ & 2.532 & .061 & \\
\hline & 2 & 37 & 74.22 & 11.46 & & & & \\
\hline & 3 & 20 & 65.70 & 11.90 & & & & \\
\hline & 4 & 22 & 70.91 & 10.8 & & & & \\
\hline & Total & 115 & 71.06 & 11.3 & & & & \\
\hline \multirow{5}{*}{ STRTGCA } & 1 & 36 & 69.11 & 10.67 & $3-111$ & 3.359 & .021 & $2-3$ \\
\hline & 2 & 37 & 72.81 & 10.58 & & & & \\
\hline & 3 & 20 & 63.75 & 11.24 & & & & \\
\hline & 4 & 22 & 72.41 & 12.18 & & & & \\
\hline & Total & 115 & 70.00 & 11.38 & & & & \\
\hline \multirow{5}{*}{ SLA } & 1 & 36 & 59.94 & 13.37 & $3-111$ & 7.153 & .000 & $\begin{array}{l}1-2 \\
2-4\end{array}$ \\
\hline & 2 & 37 & 69.70 & 9.90 & & & & \\
\hline & 3 & 20 & 62.40 & 10.86 & & & & \\
\hline & 4 & 22 & 56.27 & 12.85 & & & & \\
\hline & Total & 115 & 62.81 & 12.73 & & & & \\
\hline \multirow{5}{*}{ LA } & 1 & 36 & 199.94 & 28.95 & $3-111$ & 4.243 & .007 & $2-3$ \\
\hline & 2 & 37 & 216.73 & 27.28 & & & & \\
\hline & 3 & 20 & 191.85 & 29.75 & & & & \\
\hline & 4 & 22 & 199.59 & 25.75 & & & & \\
\hline & Total & 115 & 203.87 & 29.15 & & & & \\
\hline
\end{tabular}

According to Table 3, as the Achievement Focused score means of the prospective visual arts teachers according to the grade variable are analysed, it is seen that one way ANOVA results do not indicate any significant difference $[\mathrm{F}(3-111)=1.07 \mathrm{p}>.05]$. In the Table, also, as the standard deviation values of the students related to the Academic Motivation scores in terms of grade variable are analysed, it is understood that 1st grade university students have more homogenous evaluation $(\mathrm{s}=18.12)$ compared with the 2 nd grade $(\mathrm{s}=20.39)$, 3rd grade $(\mathrm{s}=$ $27.06)$ and 4th grade $(s=22.67)$ students. Besides, the Learning Approaches of the pre-service teachers and the difference between the mean scores related to their sub-dimensions were analysed. According to the Table, except from the In-Depth Learning Approach $[\mathrm{F}(3-111)=2.53, \mathrm{p}>.05]$, significant difference was found between the mean scores of Superficial Learning Approach $[\mathrm{F}(3-111)=7.153, \mathrm{p}<.05]$, Strategic Approach $[\mathrm{F}(3-111)=3.359$, $\mathrm{p}<.05]$ and Learning Approach[F(3-111) $=4.243, \mathrm{p}<.05]$. In the TUKEY test, applied to find out which groups had the difference, it was found that the difference occurred between the 2nd and 3rd grades for the Strategic Approach, 1st and 2nd, and 2nd and 4th grades for the Superficial Learning Approach, 2nd and 3rd grades for the Learning Approach. The decrease in learning approaches in the last years can be explained by the fatigue experienced by years.

3.4 Findings Related to the Relationship Between the Achievements Focused Motivation, Learning Approaches Scale (In-Depth Learning Approach, Strategic Approach, Superficial Learning Approaches), General Weighted Mean Scores of the Prospective Visual Arts Teachers

The Pearson Correlation test results for the relationship between the Achievement Focused Motivation, Learning Approaches Scale (In-Depth Learning Approach, Strategic Approach, Superficial Learning Approaches) and General Weighted Mean Scores of the prospective visual arts teachers are presented in Table 4. 
Table 4. The results related to the correlation analysis calculated to determine relationship between the achievement focused motivation, learning approaches scale (in-depth learning approach, strategic approach, superficial learning approaches) and general weighted mean scores of the prospective visual arts teachers

\begin{tabular}{|c|c|c|c|c|c|c|c|}
\hline & & AFMS & ILA & STRTGCA & SLA & LA & GWMS \\
\hline AFMS & & 1 & .860 & .817 & .535 & .827 & .086 \\
\hline & $\mathrm{p}$ & & .000 & .000 & .000 & .000 & .358 \\
\hline & $\mathrm{n}$ & 117 & 117 & 117 & 117 & 117 & 115 \\
\hline ILA & & & 1 & .887 & .565 & .917 & .172 \\
\hline & $\mathrm{p}$ & & & .000 & .000 & .000 & .067 \\
\hline & $\mathrm{n}$ & & 117 & 117 & 117 & 117 & 115 \\
\hline STRTGCA & & & & 1 & .610 & .934 & .171 \\
\hline & $\mathrm{p}$ & & & & .000 & .000 & .068 \\
\hline & $\mathrm{n}$ & & & 117 & 117 & 117 & 115 \\
\hline SLA & & & & & 1 & .819 & -.152 \\
\hline & $\mathrm{p}$ & & & & & .000 & .104 \\
\hline & $\mathrm{n}$ & & & & 117 & 117 & 115 \\
\hline LA & & & & & & 1 & .067 \\
\hline & $\mathrm{p}$ & & & & & & .476 \\
\hline & $\mathrm{n}$ & & & & & 117 & 115 \\
\hline GWMS & & & & & & & 1 \\
\hline & $\mathrm{p}$ & & & & & & \\
\hline & $\mathrm{n}$ & & & & & & 115 \\
\hline
\end{tabular}

In Table 4, the relationship between the Achievement Focused Motivation, Learning Approaches Scale (In-Depth Learning Approach, Strategic Approach, Superficial Learning Approaches) and General Weighted Mean Scores are analysed. According to the Table, it is observed that there is a positive high level of relationship between the Achievement Focused Learning Approach (.827), In-Depth Learning approach (.860), Strategic Approach (.817); positive moderate relationship between the Superficial Learning Approach; and low relationship between the Achievement Focused Motivation and GWMS (.086). The low relationship between achievement-focused motivation and GWMS is a significant finding. Besides, the low relationship between the GWMS and Learning Approaches noteworthy in the research $(.171, .172,-.152, .067)$. As it is understood from the Table, as expected, a positive and high relationship was found between the learning approach and its sub-dimensions (In-Depth Learning approach .912, Superficial Learning Approach .819, Strategic Approach .934).

\section{Discussion}

For the first finding of the study, as the highest score from the scale is 175 is considered, it is concluded that the prospective teachers' mean scores of achievement focused motivation are quite high. Another study conducted by Ergin and Karatas (2018), it was determined that the achievement focused motivation levels of the students tend to be high. In the research, aimed to find out the academic motivation levels of the prospective music teachers, Kucukosmanoglu (2015) reached to the result that the intrinsic motivations of the prospective teachers related to the achievement were at a high level. In the research by Taskesen (2019), it was found that the Academic Motivations of the prospective visual arts teachers were at a high level. In the research by Gomleksiz and Serhatlioglu (2013), the intrinsic motivations of the pre-service teachers related to the achievement were determined to be at a medium level. Other researches support the finding that the achievement focused motivations of the pre-service teachers are high.

Besides, as the score means of the pre-service teachers related to the Learning Approaches and their sub-dimensions are taken into consideration, it is seen that the ILA $=69.85$, STRTGCA $=68.80, \mathrm{SLA}=61.74$ and $\mathrm{LA}=200.38$. The highest score that can be gotten from each sub-dimensions is 90; from the Learning Approach Scale is 270 . Considering this, it can be referred that the mean scores of the prospective visual arts teachers in the Strategic Approach and In-Depth Learning Approach are good; the Superficial Learning Approach score means are at the medium level. The mean scores of the Learning Approach can be defined as a good level. In the similar research by Ekinci (2009), a definite level was not found in the mean scores of the students related to the approaches both in general and in terms of a learning approach within the scope of universities. 
According to another finding, as the Achievement Focused Motivation (AFM) mean scores of the female and male prospective visual arts teachers are compared, it is seen that the mean scores of the female participants are higher than male participants. However, it is observed that the difference between the scores according to gender is not significant. In the study by Bektas and Karagoz (2017) called as Investigation of the Attitude and Motivation Levels of Pre-service Teachers in Terms of Some Variables, it was found that there was no difference in terms of gender. As similar studies related to the gender variable of research were taken into consideration, in addition to the supporting studies, the studies with different results from study were also encountered. In the studies by Ergin and Karatas (2018), and Eymur and Geban (2011), it is seen that the mean scores of the female students are significantly higher than the score means of the male ones. In the study conducted by Taskesen (2019), it was concluded that the Achievement Focused Intrinsic Motivation scores of the female students were higher than male students. On the other hand, in the research by Tekin et al. (2009), in which the motivations of the pre-service physical education teachers were determined, the academic motivations of the male pre-service teachers were found to be higher.

According to Table 2, also, as the mean scores of female and male visual arts teachers Learning Approaches (LA) and its sub-dimensions; In-Depth Learning Approach (ILA), Strategic Approach (STRTGCA), Superficial Learning Approach (SLA) are compared, it is seen that the Learning Approaches mean score of the male pre-service teachers $=205.55$ is higher than the mean score of female pre-service teachers $=203.89$; in the sub-dimensions of the Learning Approaches, it is high in favour of the male participants. İt was found that the difference between the scores of the female participants and male participants was not significant. In addition to the results, it is understood that there is no difference between the Learning Approaches and In-Depth Learning Approaches, Strategic Approaches, Superficial Learning Approaches of the female and male prospective visual arts teachers. In the research by Senemoglu (2011), which is among the similar researches, it was determined that there was no significant difference between the female and male students in terms of the strategic and superficial learning approaches. Considering this, it was found that female students preferred the strategic and superficial approach considerably compared with the male students. In the study by Ozan, Kose, and Gundogdu (2012), it was determined that among the learning approaches preferences of the students according to the gender variable, a significant difference was found only in the superficial learning approach of the students. According to this, male students prefer the superficial learning approach considerably compared with the female students. An In-Depth and strategic learning approach, no meaningful difference was encountered between the female and male students. In the study by Ozgur and Tosun (2012), it was determined that the learning approach differed in terms of the gender variable. It was found that male students preferred the superficial learning approach more compared with females. In a similar study by Selcuk, Caliskan, and Erol (2007), it was determined that the learning approaches of the pre-service physics teachers did not demonstrate a difference in terms of gender variable.

In another finding of the present study, as the mean scores of the prospective visual arts teachers in terms of the Achievement Focused Motivation levels according to the grade level variable were analysed, no significant difference was encountered. In the study by Taskesen (2019), as the Academic Motivation mean scores of the prospective visual arts teachers according to the grade variable were taken into consideration, an increase was noticed from the 1st grade to 4th grade. However, this difference was noticed to be not significant. In the study by Ergin and Karatas (2018), it was found that the grade variable was a meaningful variable on the achievement focused motivation levels of the students and the Extrinsic Effects sub-dimension. In the study by Tekin et al. (2009), it was determined that the motivation levels of the pre-service visual arts teacher in 4th grade were higher compared with the others. However, in the studies by Eymur and Geban (2011), O. Gencay and S. Gencay (2007), Gomleksiz and Serhatlioglu (2013), and Gursimsek (2002), it was noticed that the prospective teachers in 1st grade had higher academic motivation levels than the students in other grade levels.

Besides, the Learning Approaches of the prospective teachers and mean score differences according to its sub-dimensions were analysed. According to the table, except for the In-Depth Learning Approach, a significant difference was found between the score means of the Superficial Learning Approach, Strategic Learning Approach and Learning approach. The difference was found between the 2nd and 3rd grade levels for the Strategic Learning Approach; 1st and 2nd; and 3rd and 4th grade levels for the Superficial Learning Approach; the difference for the Learning Approach was encountered between the 2nd and 3rd grades. In the researched by Ozan, Kose, and Gundogdu (2012), among the learning approaches of the students in terms of the grade level variable, a significant difference was encountered only in the superficial learning approach. In In-Depth learning and strategic learning approaches, a significant difference was not encountered according to the variable of grade level. The results of the study by Ozgur and Tosun (2012) demonstrated that the age and learning grade level variables did not have any effect on learning approaches. In the study, Ekinci (2009) proved that the mean scores of the strategic learning 
approach did not demonstrate any significant difference between the superficial learning approaches related to the grade level; however, the difference was found in favour of 1st grade in terms of both strategic and superficial learning approaches. In the compare the means related to the In-Depth learning approach according to the grade level, it was found that there was no significant difference in terms of grade level between the 1st and 4th grade mean scores and this result may be related to the lack of adequate features of the teaching-learning environment in universities.

In another finding, the relationship between the mean scores of the Achievement Focused Motivation, Learning Approaches Scale (In-Depth Learning Approach, Strategic Approach, Superficial Learning Approach) and the General Weighted Mean scores were investigated. According to the Table, it was found that positive and high level of relationship was encountered between the Achievement Focused Motivation and Learning Approaches (.827), In-Depth Teaching Approach (.860), Strategic Approach (.817); and a positive and medium level of relationship with the Superficial Learning Approach. There is a low relationship between the Achievement Focused Motivation and GWMS (.086). In addition to the fact that the relationship between Achievement Focused Motivation and GWMS is low, there are some similar studies. In the study, conducted by Yilmaz, O. Taskesen, and S. Taskesen (2016), it was found that there was no significant relationship between academic achievement and academic motivation. In the study by Taskesen (2019), it was seen that the relationship between Academic Motivation and GWMS was low. Besides, among the similar studies, in the study by Ergin and Karatas (2018), contrary to research, a positive significant relationship was found between the sub-dimensions of the achievement focused motivation and the academic achievement.

Besides, the low relationship between GWMS and Learning Approaches is noteworthy. As it is understood from the results, as it was expected, a positive high relationship was encountered between the learning approach and its sub-dimensions (In-Depth Learning approach, 912, Superficial Learning Approach .819, Strategic Approach .934). Furthermore, in the study by Ekinci (2009), which is among the similar researches, it was found that the learning approaches scores of the pre-service teachers were affected by the success status of them and while the high achievement level is associated with the In-Depth and strategic learning approaches, low achievement can be associated with the superficial learning.

As a result, it can be claimed that the achievement-focused motivations of the prospective visual arts teachers are at a good level for them to achieve their fields, and that prospective teachers' adoption of Strategic Approach and In-depth Learning Approach may also be effective in their success. Although it was founded that the achievement focused motivation level and learning approaches do not change according to gender in the study, it was concluded that different findings could be reached when evaluated with the findings of other related studies. As it was expected in the study, as the grade level increased, the In-depth Learning Approach scores and Strategic Approach scores increased and superficial learning scores decreased. It is understood that gender does not play a role in learning approaches and in-depth learning approaches, strategic approaches, superficial learning approaches of the prospective visual arts teachers. A significant difference was encountered in the dimension of learning approaches according to grade level. It is observed that the In-depth Learning Approach and Strategic Approach scores increase and the Superficial Learning Approach scores decrease, especially as the grade level increases. A positive and high-level relationship in the Achievement Focused Motivation Learning Approaches, In-depth Teaching Approach, Strategic Approach, a positive but moderate relationship between superficial learning approach are regarded as normal considering the quality of learning approaches. The weak relationship between achievement-focused motivation and GWMS is a significant result.

\section{Suggestions}

It is recommended to carry out activities that will contribute to the achievement focused motivation development of the students. Students may be given additional work to contribute to their academic achievement.

Students' learning approaches are influenced by university, grade-level variables; for this reason, it can be ensured that students can get to a better level with the right orientation.

In educational institutions, learning environments can be established to enable students to turn to an In-Depth learning approach. For example, students can be assigned to do research on the subject. Topics can be converted into projects.

It may be beneficial to repeat the study in different samples by considering the variable and cultural factors that affect students' learning approaches.

Experimental studies can be conducted to examine the effects of different learning environments on learning approaches. 


\section{References}

Ames, C. (1990). Motivation: what eachers need to know. Teachers College Record, 91(3), 409-421.

Bektas, M., \& Karagoz, S. (2017). Ogretmen adaylarinin tutum ve motivasyon duzeylerinin bazi degiskenler acisindan incelenmesi (Invenstigation of attitudes and motivation levels of teacher candidates in terms of some variables). International Journal of Academic Value Studies (Javstudies), 3(15), 154-164. https://doi.org/10.23929/javs.565

Biggs, J. B. (1987). Student approaches to learning and studying. Melbourne: Australian Council for Educational Research.

Biggs, J.B. (Ed.) (1991). Teaching for learning: The view from cognitive psychology. Hawthorn, Victoria: Australian Council for Educational Research.

Buyukozturk, S., Kilic, Cakmak, E., Akgun, O., Karadeniz, S., \& Demirel, F. (2012). Bilimsel arastirma yöntemleri. Ankara: Pegem Akademi.

Chan, K. (2003). Hong Kong teacher education students' epistemological beliefs and approaches to learning. Research in Education, 69, 36-50. https://doi.org/10.7227/RIE.69.4

Cuceloglu, D. (1999). Insan ve davranisi [Human and behavior] (9th ed.). Istanbul, Turkey: Remzi.

Deci, E. L., \& Ryan, R. M. (1985). Intrinsic motivation and self determination in human behavior. New York: Plenum. https://doi.org/10.1007/978-1-4899-2271-7

Deci, E. L., \& Ryan, R. M. (2000). The "what" and "why" of goal pursuits: human needs and the self-determination of behavior. Psychological Inquiry, 11, 227-268. https://doi.org/10.1207/S15327965PLI1104_01

Ekinci, N. (2008). Universite ogrencilerinin ogrenme yaklasimlarinin belirlenmesi ve ogretme-ogrenme sureci degiskenleri ile iliskileri (Related to the learning approach of university learning and teaching-learning process variables). $\mathrm{PhD}$ thesis, Hacettepe University İnstitute of Social Sciences, Ankara.

Ekinci, N. (2009). Universite ogrencilerinin ogrenme yaklasimlari (Learning approaches of university students). Education and Science, 34(151), 74-88.

Ekinci, N. (2015). Ogretmen adaylarinin ogrenme yaklasimlari ve ogretmen ozyeterlik inanclari arasindaki ilişki (The relationship between teacher approaches and teacher self-efficacy beliefs). Journal of Hacettepe University Faculty of Education, 30(1), 62-76.

Ergin, A., \& Karatas, H. (2018). Achievement-oriented motivation levels of university students. Hacettepe University Journal of Education, 33(4), 868-887. https://doi.org/10.16986/HUJE.2018036646

Eymur, G., \& Geban, O. (2011). Kimya ogretmeni adaylarinin motivasyon ve akademik basarilari arasindaki iliskinin incelenmesi [An investigation of the relationship between motivation and academic achievement of pre-service chemistry teachers]. Education and Science, 36(161), 246-255.

Gencay, O. A., \& Gencay, S. (2007). Beden egitimi ve spor yuksekokulu ogrencilerinin ogretmenlik meslegine iliskin motivasyon duzeylerinin bazi degiskenler acisindan incelenmesi [İnvestigating the motivation levels of the preservice teachers in the department of physical education and sport related to the teaching profession in terms of some variables]. Selcuk University the Journal of Institude of Social Sciences, 17, 241-253.

Geri, S. (2013). Kirgizistan'daki universite ogrencilerinin beden egitimi ve spor servis dersine tutumlari ile akademik motivasyonlarinin incelenmesi. (Investigation of attitudes and academic motivation of university students in kyrgyzstan to physical education and sports service course). Manas Journal of Social Research, 2(8), 31-46

Gomleksiz, M. N., \& Serhatlioglu, B. (2013). Ogretmen adaylarinin akademik motivasyon duzeylerine iliskin gorusleri [Prospective teachers' perceptions of academic motivation levels]. The Journal of Turkey Social Research, 17, 99-173.

Gursimsek, I. (2002). Ogretmen adaylarinda ogrenmeye iliskin motivasyonel inanclar ve strateji kullanimi [Motivational beliefs and strategy usage among pre-service teachers related to learning]. Mugla University Journal of Social Sciences, 8, 135-155.

Harlen, W., \& James, M. (1997). Assessment and learning: differences and relationships between formative and summative assessment. Assessment in Education: Principles, Policy and Practice, 4(3), 365-380. 
https://doi.org/10.1080/0969594970040304

Kanadli, S., \& Akbas, A. (2015). Fen bilgisi ogretmen adaylarinin epistemolojik inanclari(The relationship between epistemological beliefs, learning approaches and lys scores of prospective science teachers). Mersin University Journal of Education, 11(1), 116-131.

Karaguven, M. H. (2012). Akademik motivasyon olceginin Turkceye adaptasyonu [The adaptation of academic motivation scale to Turkish]. Educational Sciences in Theory and Practice, 12(4), 2599-2620.

Karatas, H. (2011). Universite ogrencilerinin epistemolojik inanclari, ogrenme yaklasimlari ve problem cozme becerilerinin akademik motivasyonu yordama gucu, (Epistemological beliefs, learning approaches and problem solving skills of university students predict academic motivation) (Unpublished doctoral dissertation). Yildiz Technical University İnstitute of Social Sciences, İstanbul.

Kaur, S. (2013). Academic achievement in relation to achievement motivation of high school students. International Journal of Science and Research, 2(12), 409-411.

Kayar, Z. (2004). Gelisim ve ogrenme ders notlari [Development and learning lecture notes]. Genisletilmis 2. Baski. İstanbul.

Kucukosmanoglu, H. O. (2015). Muzik ogretmeni adaylarinin akademik motivasyon duzeylerinin belirlenmesi uzerine bir calisma (Konya ili ornegi) [A research on the determination of prospective music teachers' academic motivation levels (Konya sample)]. Journal of Art Education, 3(1), 1-21. https://doi.org/10.7816/sed-03-01-01

Liao, H., Ferdenzi, A. C., \& Edlin, M. (2012). Motivation, self-regulated learning efficacy, and academic achievement among international and domestic students at an urban community college: A comparison. Community College Enterprise, 18, 9-38.

Marton, F., \& Saljo, R. (1976a). On qualitative differences in learning. I outcome and process. British Journal of Educational Psychology, 46, 4-11. https://doi.org/10.1111/j.2044-8279.1976.tb02980.x

Marton, F., \& Saljo, R. (1976b). On the qualitative differences in learning. II outcome and process. British Journal of Educational Psychology, 46, 115-127. https://doi.org/10.1111/j.2044-8279.1976.tb02304.x

McClelland, D. C. (1961). The Achieving society (p.493). D. Van Nostrand Company Inc., Princeton, New Jersey. https://doi.org/10.1037/14359-000

Olpak, Y., Z., \& Korucu, A. T. (2014). Ogretmen adaylarinin ogrenme yaklasimlari ile denetim odaklari arasindaki iliskinin incelenmesi (Examining the relationship between prospective teachers' learning approaches and control foci). Egitim Teknolojisi Kuram Ve Uygulama/Educational Technology Theory and Practice, 4(2), 75-91. https://doi.org/10.17943/etku.83050

Oncu, H. (2000). Motivasyon [Motivation]. L. Kucukahmet (Ed.), Sinif yonetimi [Classroom Management] (pp. 159-182). Ankara, Turkey: Nobel.

Ozan, C., \& Cifti, M. (2013). Egitim fakultesi ogrencilerinin ogrenme yaklasimlari tercihleri ve ogrenmeye iliskin algilarinin incelenmesi (İnvestigation of Perceptions of Students of Faculty of Education on Learning Approaches Preferences and Learning). Pegem Journal of Education and Training, 3(1), 55-66. https://doi.org/10.14527/C3N1M5

Ozan, C., Kose, E., \& Gundogdu, E. (2012). Okul oncesi ve sinif ogretmenligi ogrencilerinin ogrenme yaklasimlarinin incelenmesi (Investigation of Learning Approaches of Preschool and Primary School Students). Journal of Educational Sciences Research, 2(2), 75-92.

Ozgur, H., \& Tosun, N. (2012). Ogretmen adaylarinin derin ve yuzeysel ogrenme yaklasimlarinin cesitli degiskenler acisindan incelenmesi (Investigation of pre-service teachers' deep and surface learning approaches in terms of various variables). Mehmet Akif Ersoy University Journal of Education Faculty, 24, 113-125.

Ramsden, P. (1979). Student learning and perceptions of the academic environment. Higher Education, 8 , 411-427. https://doi.org/10.1007/BF01680529

Ramsden, P. (2003). Learnig to teaching in higher education (2nd ed.). London: Routhladge Falmer.

Saritepeci, M. (2018). Beklenti-deger teorisini temel alan basari motivasyonu olcegini uyarlama calismasi. Journal of Education Science and Technology, 4(1), 28-40.

Selcuk, G., S., Calıskan, S., \& Erol, M. (2007). The effects of gender and grade levels on Turkish physics teacher 
candidates' problem solving strategies. Journal of Turkish Science Education (TUSED), 4(1), 92-100.

Semerci, C. (2010). Basari odakli motivasyon (BOM) olceginin geliştirilmesi. e-Journal of New World Sciences Academy Education Sciences, 1C0261, 5(4), 2123-2133.

Taskesen, S. (2019). Investigating the academic motivations and academic achievements of prospective visual arts teachers. European Journal of Educational Research, 8(3), 857-155. https://doi.org/10.12973/eu-jer.8.3.857

Tekin, M., Tasgin, O., Yildiz, M., \& Lok, S. (2009, June). Beden egitimi ve spor yuksekokulunda ogrenim goren ogretmen adaylarinin ogretmenlik meslegine iliskin motivasyon duzeyleri (The motivation levels of the pre-service teachers in the department of physical education and sport related to the teaching profession). Paper presented at the 6th Symposiom of National Department of Physical Education and Sport. Mehmet Akif University, Burdur, Turkey.

Yildirim, A., \& Simsek, H. (2006). Sosyal bilimlerde nitel arastirma yontemleri. Ankara: Seckin Yayincilik.

Yilmaz, E. (2014). Guclu yon temelli yaklasimin yuksekogretimde ingilizce dersinde devam, akademik basari ve motivasyon uzerindeki etkisinin incelenmesi (Investigation of the Effect of the Strong Way Based Approach on Attendance, Academic Success and Motivation in English Lesson in Higher Education) (Unpublished doctoral dissertation). Firat University, Elazig.

Yilmaz, E. (2017). Ogretmen adaylarinin benimsedikleri egitim felsefeleri ile basari motivasyonlari arasindaki iliskiler (Relationships between Teacher Education Trainees' Philosophies and Achievement Motivation). Bartin University, Faculty of Education Journal, 6(3), 1420-1429. https://doi.org/10.14686/buefad.346494

Yilmaz, M., Taskesen, O., \& Taskesen, S. (2016). A Study on department of fine arts education students' level of academic motivation according to some variables the relation between their academic motivation and academic success. Journal of Erzincan University Education Faculty, 18(2), 1056-1072.

\section{Copyrights}

Copyright for this article is retained by the author(s), with first publication rights granted to the journal.

This is an open-access article distributed under the terms and conditions of the Creative Commons Attribution license (http://creativecommons.org/licenses/by/4.0/). 